\title{
Identification of Mutations, Expression Alterations and Fusion Transcripts by Next Generation RNAseq in Castration-Resistant Prostate Cancer Cell lines with Possible Clinical Relevance
}

\author{
Yuanjun Ma ${ }^{1 \#,}$ Yali Miao ${ }^{2 \#}$, Zhuochun Peng ${ }^{1}$, Johanna Sandgren ${ }^{1}$, Teresita Díaz De Ståhl ${ }^{1}$, Lena Lennartsson ${ }^{1}$, Sten Nilsson $^{1,3}$ and Chunde Li ${ }^{1,3^{*}}$ \\ ${ }^{1}$ Department of Oncology-Pathology, Karolinska Institute, Stockholm, Sweden \\ ${ }^{2}$ West China Second University Hospital/West China Women's and Children's Hospital, Sichuan University, Chengdu, China \\ ${ }^{3}$ Department of Clinical Oncology, Karolinska University Hospital, Stockholm, Sweden \\ \#Equally Contributed
}

"Corresponding author: Chunde Li, Associate Professor, Department of Oncology, CCK R8:04 Karolinska University Hospital, Stockholm 17176, Sweden, Tel: +46 703888984; E-mail: chunde.li@ki.se

Rec date: September 01, 2017; Acc date: September 19, 2017; Pub date: September 21, 2017

Copyright: (c) $2017 \mathrm{Ma} \mathrm{Y}$, et al. This is an open-access article distributed under the terms of the creative commons attribution license, which permits unrestricted use, distribution, and reproduction in any medium, provided the original author and source are credited.

\begin{abstract}
Androgen Deprivation Therapy (ADT) would benefit prostate cancer patients initially but cancer cells can eventually develop castration resistance. In this study, we compared androgen-dependent and androgenindependent cell lines to find potential genes associated with acquired resistance to ADT. Using RNAseq, we found 4397 mutations distributed in 2579 genes, out of which, 1574 mutated genes could also be found in prostate cancer tumor samples collected in Cosmic database (http://cancer.sanger.ac.uk/cosmic). We also discovered 157 and 549 genes which were down and up-regulated respectively in both PC3 and DU145 compared to LNCaP. Network analysis resulted in 3 dominant connection notes: GCR/MCR (NR3C1) and PKA-cat kinase (PRKACB) and PKC family (PRKD1). By ChimeraScan analysis, 48, 117 and 60 chimeric transcripts were discovered in DU145, LNCaP and PC3 respectively. Among them, six predicted fusions expressed specifically in androgen-independent cell lines (DU145 and PC3). Some of these gene mutations and transcription alterations have been reported in tumor samples from prostate cancer patients and may have certain associations with acquired resistance to anti-hormone therapy in prostate cancer. A proportion of mutations are enriched in genes involved in immune response pathways, suggesting new targets to develop effective treatments to overcome castration resistance.
\end{abstract}

Keywords: Androgen resistance; Prostate cancer; RNAseq; Mutations; Gene fusions; Altered expressions; Transcription alterations

\section{Introduction}

Prostate cancer is the third most common cause of death from cancer in men in Europe [1]. Androgen deprivation therapy (ADT), as a first-line therapy, usually leads to a response with suppression of prostate specific antigen (PSA) levels, symptomatic palliation and prolonged overall survival in most patients. However, all patients would eventually become resistant to the treatment and median overall survival after ADT is 48 to 54 months [2,3]. Metastatic castrationresistant prostate cancer ( $\mathrm{mCRPC}$ ) is the main cause of cancer death in prostate cancer patients.

It has been shown that prostate cancer cells can grow and proliferate at low or even near-zero androgen levels when they become castration resistant [4]. A hypersensitive androgen receptor (AR) pathway can be evolved through accumulation of molecular alterations including AR overexpression, gain of function mutations in AR gene, transcriptional activity of the AR altered by coactivators or corepressors, intra-tumoral testosterone synthesis, and ligand-independent activation of AR [5]. Other alterations includes a) changes in growth factor and corresponding receptors, e.g. transforming growth factor a (TGFa), epidermal growth factor (EGF), basic fibroblast growth factor (bFGF), keratinocyte growth factor (KGF), insulin-like growth factor-1 (IGF-1)
[6-10], b) apoptotic signaling e.g. phosphatase and tensin homolog (PTEN), bcl-2 and Myb [11-13], and c) Wnt/ $\beta$-catenin signaling [14].

Despite vigorous efforts only a few prostate cancer cell lines have been established. Among them, LNCaP was derived from a lymph node metastasis. It is androgen-dependent and can represent the early stage of metastatic prostate cancer. PC3 and DU145 were derived from bone and brain metastases respectively. They are androgenindependent and can represent the later and rapid progressing metastatic prostate cancer stage. In this article, we compared androgen-independent cell lines (PC3 and DU145) versus androgendependent cell line (LNCaP) to discover which genomic changes are possibly connected to the development of castration resistance.

\section{Methods}

\section{RNAseq}

Total RNA was extracted by TRIzol (Invitrogen, Catalog \#15596018) following by phenol/chloroform. RNA Integrity Number (RIN) was used to control RNA quality by Agilent 2100 Bioanalyzer System. PolyA selection from total RNA samples was done in SciLifeLab, Stockholm, and sequencing was conducted on HiSeq 2000 according to manufacturer's instructions. 
Citation: Ma Y, Miao Y, Peng Z, Sandgren J, Díaz De Ståhl T, et al. (2017) Identification of Mutations, Expression Alterations and Fusion Transcripts by Next Generation RNAseq in Castration-Resistant Prostate Cancer Cell lines with Possible Clinical Relevance. Next Generat Sequenc \& Applic 4: 149. doi:10.4172/2469-9853.1000149

Page 2 of 8

\section{Analysis of mutations, differentially expressed and fusion genes}

RNAseq fastq data was aligned to reference genome hg38 by STAR 2 pass and GATK (base quality score recalibration, indel realignment, duplicate removal and INDEL discovery) was applied to call variants across all 15 samples according to GATK Best Practices recommendations [15-17]. A published TopHat and Cufflinks protocol was used to find differentially expressed genes [18] and ChimeraScan was employed to discover fusion transcripts [18]. Panther (http:// www.pantherdb.org) and Thomson Reuters (https:// portal.genego.com) were applied for functional enrichment analysis [19].

\section{PCR validation}

We used cloned AMV first-strand synthesis kit (Life Technologies, Catalog \# 12328) and PCR to validate expressions and fusions. Forward primer for fusion transcripts was designed upon fusion sequence given by RNAseq. The forward primer located in 5' gene and reverse primer on the 3' gene. PCR was done by Platinum Taq DNA polymerase (Life Technologies, Catalog \#10966018), followed by Sanger sequencing in Eurofins Genomics.

\section{Results}

\section{Mutations acquired in castration resistant cell lines}

We used triplicates of each cell line (Du145, PC-3 and LNCaP) for whole transcriptome RNA-sequencing and compared "hormone resistant" (PC-3 and DU145) and "hormone sensitive" (LNCaP) cell lines to find mutations acquired after hormone treatment. Only mutations, which were present in PC-3 and Du145 but absent in LNCaP triplicates were chosen as "stably acquired mutations".

We found, in 2579 genes, 4397 mutations which were consistently mutated after cell lines acquired resistance to hormone treatment (S1). All 2579 mutated genes distributed relatively even in all chromosomes without preference. GO term analysis showed that binding (GO: 0005488) and catalytic activity (GO:0003824) are two most widely distributed groups among all mutated genes (Figure 1A), and the two most enriched pathways are 1) Immune response B cell antigen receptor (BCR) pathway, and 2) development positive regulation of STK3/4 (Hippo) pathway and negative regulation of YAP/TAZ function.

\begin{tabular}{|c|c|c|c|c|c|c|}
\hline Gene & Full name & $\begin{array}{c}\text { COMIC } \\
\text { mutation rate } \\
\text { in Pca \% }\end{array}$ & $\begin{array}{l}\text { COSMIC } \\
\text { mutation rate in } \\
\text { all cancers } \%\end{array}$ & $\begin{array}{l}\text { Protein Expression in } \\
\text { PCa Tissue (Human } \\
\text { Protein ATLAS) }\end{array}$ & $\begin{array}{l}\text { Possibly Involved } \\
\text { in immune } \\
\text { response }\end{array}$ & $\begin{array}{l}\text { Possibly } \\
\text { Involved in } \\
\text { EMT* }^{*}\end{array}$ \\
\hline$K-R A S$ & KRAS Proto-oncogene & 3.0 & 19.2 & Up-regulated & Yes $^{15}$ & Yes $^{16}$ \\
\hline PLCG1 & Phospholipase C gamma 1 & 1.2 & 1.5 & No alteration & Yes $^{17}$ & Yes $^{18}$ \\
\hline $\mathrm{NOTCH} 1$ & Translocation-associated Notch protein TAN-1 & 1.4 & 5.7 & No alteration & Yes $^{19}$ & Yes $^{20}$ \\
\hline NCOR2 & Nuclear receptor corepressor 2 & 1.4 & 1.8 & No alteration & Yes $^{21}$ & Yes $^{22}$ \\
\hline JAK1 & Janus kinase 1 & 1.3 & 1.3 & Up-regulated & Yes $^{23}$ & Yes $^{24}$ \\
\hline FASN & Fatty acid synthase & 1.1 & 1.7 & Up-regulated & Yes $^{25}$ & Yes $^{26}$ \\
\hline PREX1 & $\begin{array}{l}\text { Phosphatidylinositol-3,4,5-trisphosphate } \\
\text { dependent rac exchange factor } 1\end{array}$ & 1.1 & 1.6 & Up-regulated & $\mathrm{Yes}^{27}$ & $\mathrm{Yes}^{28}$ \\
\hline MYLK & Myosin light chain kinase & 1.4 & 1.7 & N/A & - & Yes $^{29}$ \\
\hline
\end{tabular}

Table 1: Selected mutated genes from 10 enriched pathways in Figure 1B [15-29].

Some mutations among these 10 enriched pathways had a higher mutation rate in patient samples (COSMIC) and many of them are involved in immune response (Figure 1B) (Table 1). Cosmic database shows that there are 22909 genes mutated in 4763 prostate cancer tumor samples in total, and 1574 of the 2579 genes mutated in our cell line study showed also mutations in tumor samples from patients.

\section{Genes with alternative expressions in castration resistant cell lines}

By comparation of "PC3 vs LNCaP" and "DU145 vs LNCaP", we aimed to identify down- or up-regulated genes in androgen- independent cell lines (S2). We set a cut-off (expression fold-change more than 3 and expression more than 3) and found 157 and 549 genes which were down- and up-regulated respectively in both PC3 and DU145 compared to LNCaP (S3). We selected 30 genes randomly and 28 out of them were validated by PCR (S4). The most up- or downregulated genes were shown in Tables 2 and 3.

All up- and down-regulated genes in androgen independent PC3 and DU145 cell lines (706 genes) were analyzed by MetaCore from Thomson Reuters to build network which resulted in 3 dominant connection notes (Figure 1C): GCR/MCR (NR3C1) and PKA-cat kinase (PRKACB) and PKC family (PRKD1). 
Citation: Ma Y, Miao Y, Peng Z, Sandgren J, Díaz De Ståhl T, et al. (2017) Identification of Mutations, Expression Alterations and Fusion Transcripts by Next Generation RNAseq in Castration-Resistant Prostate Cancer Cell lines with Possible Clinical Relevance. Next Generat Sequenc \& Applic 4: 149. doi:10.4172/2469-9853.1000149

A

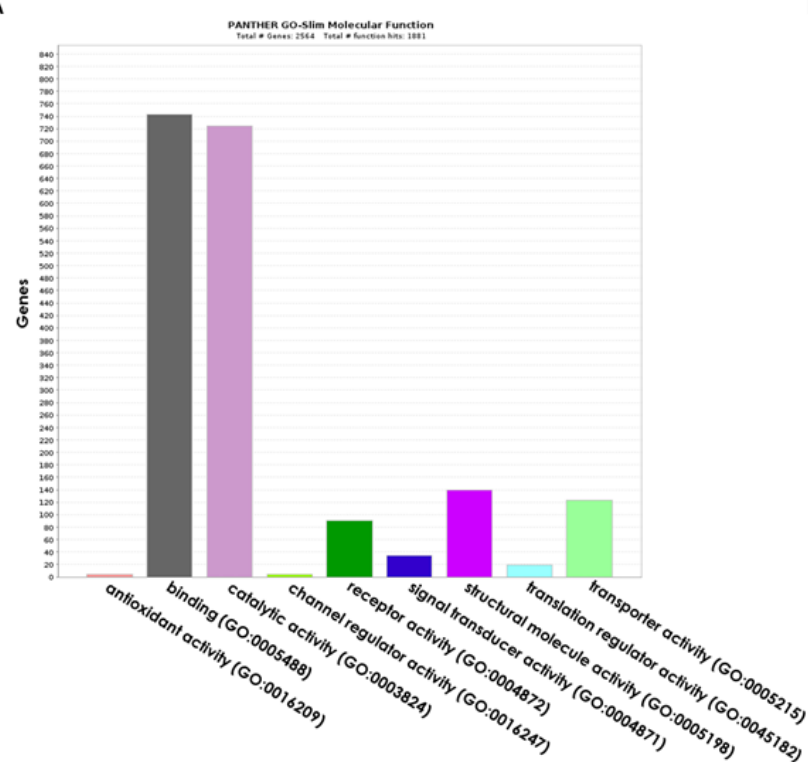

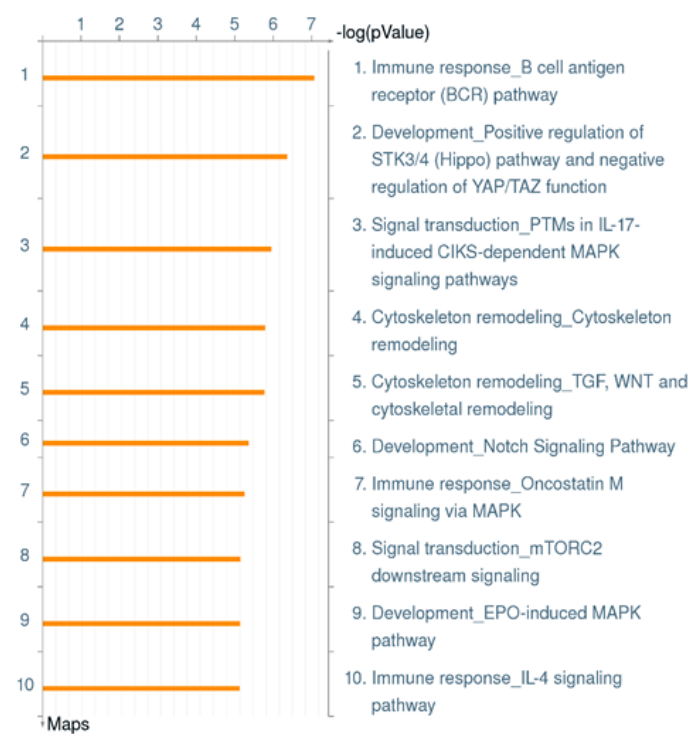

C ORP-tamily

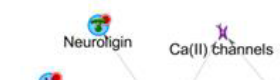

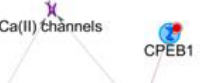

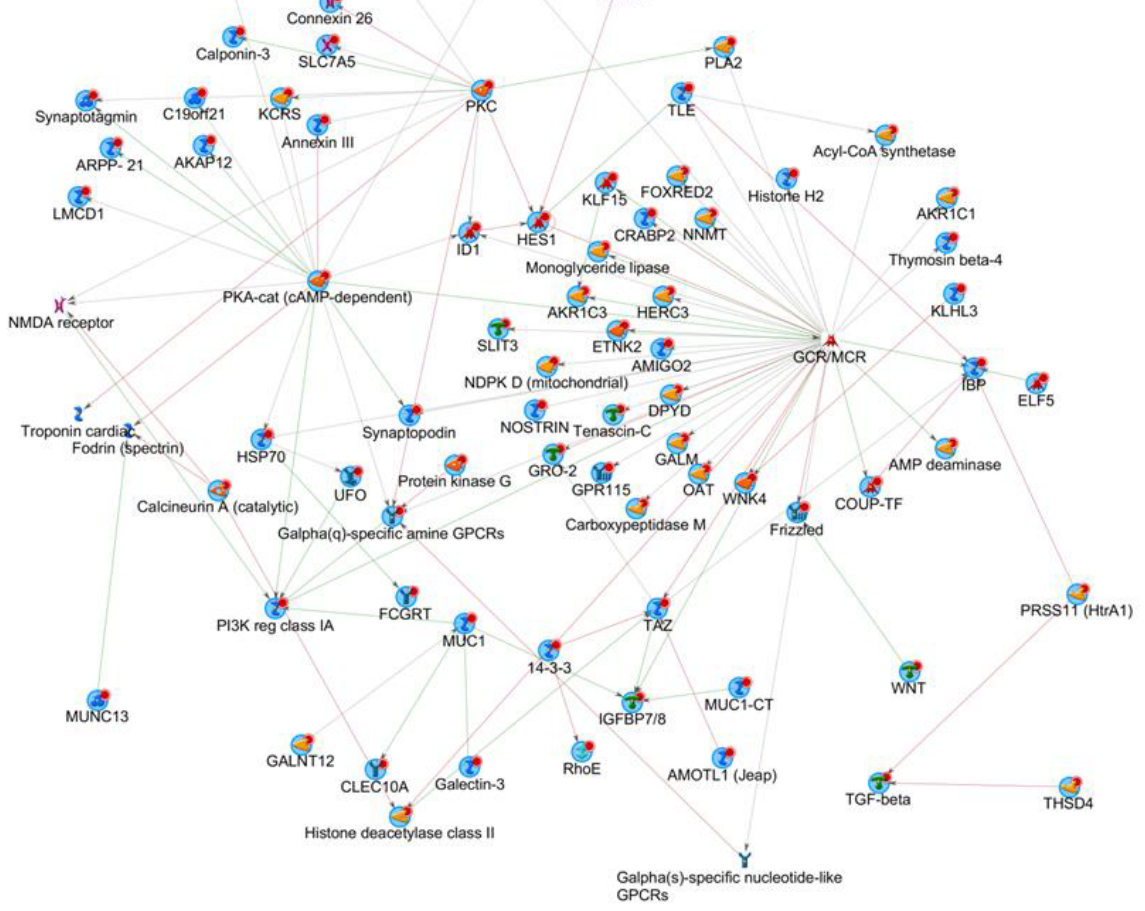

Figure 1: GO term analysis of mutations by Panther (A), pathway enrichment of mutations by MetaCore (B) and Network analysis of up/ down-regulated genes by MetaCore from Thomson Reuters (C). 
Citation: Ma Y, Miao Y, Peng Z, Sandgren J, Díaz De Ståhl T, et al. (2017) Identification of Mutations, Expression Alterations and Fusion Transcripts by Next Generation RNAseq in Castration-Resistant Prostate Cancer Cell lines with Possible Clinical Relevance. Next Generat Sequenc \& Applic 4: 149. doi:10.4172/2469-9853.1000149

Page 4 of 8

\begin{tabular}{|c|c|c|c|c|c|c|}
\hline \multirow[t]{2}{*}{ Gene* $^{*}$} & \multirow[t]{2}{*}{ Full name } & \multirow{2}{*}{$\begin{array}{l}\text { Related pathways or } \\
\text { function }\end{array}$} & \multicolumn{3}{|c|}{ Expression level } & \multirow{2}{*}{$\begin{array}{l}\text { Stably mutated in our } \\
\text { cell lines/Cosmic } \\
\text { tumor samples? }\end{array}$} \\
\hline & & & LNCaP & PC-3 & DU145 & \\
\hline INPP1 & inositol polyphosphate-1-phosphatase & Metabolism & 0.007 & 9.3 & 13.5 & Yes/Yes \\
\hline GSTP1 & Glutathione S-transferase $\mathrm{Pi} 1$ & Pathways in cancer & 0.6 & 230.1 & 363.3 & No/Yes \\
\hline CYP1B1 & $\begin{array}{l}\text { Cytochrome P450, Family } 1, \text { Subfamily B, } \\
\text { Polypeptide } 1\end{array}$ & AhR pathway & 0.03 & 14.2 & 16.2 & No/Yes \\
\hline MYEOV & Myeloma overexpressed & Myeloma & 0.1 & 45.8 & 35.5 & Yes/Yes \\
\hline KLF12 & Kruppel-like factor 12 & $\begin{array}{lr}\text { Involved in } & \text { vertebrate } \\
\text { development } & \text { and } \\
\text { carcinogenesis } & \end{array}$ & 0.01 & 6.8 & 3.3 & Yes/Yes \\
\hline GPRC5A & $\begin{array}{l}\text { G protein-coupled receptor, Class C, group } 5, \\
\text { member A }\end{array}$ & $\begin{array}{l}\text { Cancer pathway and } \\
\text { neuroscience }\end{array}$ & 0.2 & 90.6 & 58 & No/Yes \\
\hline IGFBP4 & Insulin-Like growth factor binding protein 4 & IGF binding & 0.2 & 98.7 & 50.5 & No/Yes \\
\hline CAV2 & Caveolin 2 & Prostate cancer & 0.1 & 66.3 & 27.8 & Yes/Yes \\
\hline B3GNT3 & $\begin{array}{l}\text { UDP-GIcNAc:BetaGal } \\
\text { Acetylglucosaminyltransferase } 3\end{array}$ & Metabolism & 0.04 & 27 & 10.1 & Yes/Yes \\
\hline
\end{tabular}

Table 2: Top 9 up-regulated genes when cells acquired resistance to androgen.

\begin{tabular}{|c|c|c|c|c|c|c|}
\hline \multirow[t]{2}{*}{ Gene* } & \multirow[t]{2}{*}{ Full name } & \multirow[t]{2}{*}{ Related pathways or function } & \multicolumn{3}{|c|}{ Expression level } & \multirow{2}{*}{$\begin{array}{l}\text { Stably mutated in our } \\
\text { cell lines/Cosmic } \\
\text { tumor samples? }\end{array}$} \\
\hline & & & LNCaP & PC-3 & DU145 & \\
\hline CSMD1 & CUB and Sushi multiple domains 1 & $\begin{array}{l}\text { benign adult familial myoclonic } \\
\text { epilepsy }\end{array}$ & 13.6 & 0.03 & 0.004 & No/Yes \\
\hline TMEFF2 & $\begin{array}{l}\text { Transmembrane protein with EGF-Like } \\
\text { and two follistatin-like domains } 2\end{array}$ & $\begin{array}{l}\text { function as both an oncogene and a } \\
\text { tumor suppressor depending on the } \\
\text { cellular context }\end{array}$ & 122.5 & 0.3 & 0.06 & No/yes \\
\hline SPON2 & Spondin 2, extracellular matrix protein & ERK signaling & 868.4 & 1.0 & 0.5 & No/yes \\
\hline UGT2B17 & $\begin{array}{l}\text { UDP glucuronosyltransferase } 2 \text { Family, } \\
\text { polypeptide B17 }\end{array}$ & Metabolism & 156.3 & 0.3 & 0.2 & No/Yes \\
\hline MAGEA4 & Melanoma antigen family A4 & $\begin{array}{l}\text { embryonal development and tumor } \\
\text { transformation or progression }\end{array}$ & 126.3 & 0.2 & 0.2 & No/Yes \\
\hline UGT2B15 & $\begin{array}{l}\text { UDP glucuronosyltransferase } 2 \text { family, } \\
\text { polypeptide B15 }\end{array}$ & UDP-glucuronyltransferase & 146.9 & 0.2 & 0.2 & No/Yes \\
\hline GLYATL1 & Glycine-N-acyltransferase-like 1 & Metabolism and biological oxidations & 86.1 & 0.2 & 0.2 & No/Yes \\
\hline$D D C$ & $\begin{array}{l}\text { Dopa decarboxylase (Aromatic L-amino } \\
\text { acid decarboxylase) }\end{array}$ & Metabolism & 206.7 & 0.5 & 0.7 & No/Yes \\
\hline
\end{tabular}

Table 3: Top 8 down-regulated genes when cells acquired resistance to androgen.

\section{Fusions associated with castration-resistant prostate cancer}

By ChimeraScan analysis, 117, 48 and 60 fusions were discovered in LNCaP DU145 and PC3 (S5) respectively. Venn diagram showed that only one fusion (AF086285-ATP6V1E2) was universally expressed in all 3 cell lines. Six fusions were transcribed commonly in androgenindependent cell lines (PC3 and DU145) but not in androgendependent cell line (LNCaP) (Figure 2A) (Table 4). Three of those fusion partners are long non-coding RNA (FLJ39739, LOC100286793 
Citation: Ma Y, Miao Y, Peng Z, Sandgren J, Díaz De Ståhl T, et al. (2017) Identification of Mutations, Expression Alterations and Fusion Transcripts by Next Generation RNAseq in Castration-Resistant Prostate Cancer Cell lines with Possible Clinical Relevance. Next Generat Sequenc \& Applic 4: 149. doi:10.4172/2469-9853.1000149

Page 5 of 8

and LOC728855), and a recent study showed that FLJ39739

(LINC01138) was directly AR-targeted lncRNAs and associated with

Gleason score and tumor stage [30].

\begin{tabular}{|c|c|c|c|c|c|}
\hline $\mathbf{5}$ & $\mathbf{C h r}$ & $\mathbf{5}$ ' full name & $\mathbf{3}$ & Chr & 3' full name \\
\hline CTSD & 11 & Cathepsin D & IFITM10 & 11 & Interferon Induced Transmembrane Protein 10 \\
\hline FLJ39739 & 1 & $\begin{array}{c}\text { LINC01138 long intergenic non-protein } \\
\text { coding RNA 1138 [ Homo sapiens } \\
\text { (human) ] }\end{array}$ & BC065231 & 1 & $\begin{array}{c}\text { Homo sapiens cDNA clone IMAGE:5548407, } \\
\text { partial cds }\end{array}$ \\
\hline HMGA1 & 6 & High mobility group AT-Hook 1 & BTNL8 & 5 & Butyrophilin Like 8 \\
\hline LOC100286793 & 1 & $\begin{array}{c}\text { LINC00875 long intergenic non-protein } \\
\text { coding RNA 875 }\end{array}$ & BC065231 & 1 & $\begin{array}{c}\text { Homo sapiens cDNA clone IMAGE:5548407, } \\
\text { partial cds }\end{array}$ \\
\hline LOC728855 & 1 & $\begin{array}{c}\text { LINC00623 long intergenic non-protein } \\
\text { coding RNA 623 }\end{array}$ & BC065231 & 1 & $\begin{array}{c}\text { Homo sapiens cDNA clone IMAGE:5548407, } \\
\text { partial cds }\end{array}$ \\
\hline BC110832 & 1 & $\begin{array}{c}\text { Homo sapiens cDNA clone IMAGE: } \\
5770060\end{array}$ & $B C 065231$ & 1 & $\begin{array}{c}\text { Homo sapiens cDNA clone IMAGE:5548407, } \\
\text { partial cds }\end{array}$ \\
\hline
\end{tabular}

Table 4: Fusions specifically expressed in androgen-independent cell lines (DU145 and PC3) compared to androgen-dependent cell line (LNCaP).

\begin{tabular}{|c|c|c|c|c|c|c|c|c|}
\hline 5 ' gene & 5 ' chr & $\begin{array}{l}\text { Up or down } \\
\text { regulation }\end{array}$ & 3' gene & $3^{\prime} \mathrm{chr}$ & $\begin{array}{l}\text { Up or down } \\
\text { regulation }\end{array}$ & Verified $^{*}$ & $\begin{array}{l}\text { In-frame } \\
\text { fusion }\end{array}$ & Previous publications \\
\hline MIPOL1 & 14 & no & $D G K B$ & 7 & no & Yes & No & 31 \\
\hline$A D C K 4$ & 19 & no & NUMBL & 19 & no & Yes & yes & 32 \\
\hline GPS2 & 17 & no & MPP2\# & 17 & down & yes & Yes & 33 \\
\hline TFDP1 & 13 & no & GRK1\# & 13 & down & yes & Yes & 34 \\
\hline SAMD8\# & 10 & up & $A D K$ & 10 & no & Yes & No & -- \\
\hline SMAGP & 12 & no & TFCP2\# & 12 & up & yes & No & -- \\
\hline HMGA1\# & 6 & up & BTNL8 & 5 & no & no & No & -- \\
\hline KDM5B & 1 & no & CR936711 & 1 & no & yes & No & -- \\
\hline BTNL8 & 5 & no & HMGA1\# & 6 & up & no & No & -- \\
\hline RPS24 & 10 & no & AJAP1 & 1 & no & no & No & -- \\
\hline$R E R E$ & 1 & no & PIK3CD\# & 1 & down & yes & No & 33 \\
\hline
\end{tabular}

Table 5: Fusion transcripts selected and validated by PCR [31-33].

Using "Unique alignment positions" more than 5 as a cut-off provided a total of 25 chimeric transcripts, out of which, 11 selected validations were done by PCR (Table 5). PCR validation found that eight of eleven (72.7\%) suspected fusion transcripts could be found in PC3, DU145 or LNCaP cell lines (Figure 2B). Among all the validating fusions, four chimeric transcripts (MIPOL1-DGKB, GPS2-MPP2, RERE-PIK3CD and TFDP1-GRKI) expressed only in androgendependent cell line LNCaP, while three chimeric transcripts (SMAGPTFCP2, KDM5B-CR936711, SAMD8-ADK) expressed only in androgen-resistant cell line (Figure 2C).

\section{Discussion}

The development of castration resistance can have different molecular mechanisms as given in the introduction. They can be generally classified into two major categories as AR-dependent and AR-independent. The former requires a functionally normal or hyperactive AR i.e. cancer cells have AR expression. The latter requires no direct AR functional involvement. In line with previous published results, this study showed that PC 3 and DU145 cell lines didn't express AR [34-36]. Therefore, possible molecular changes found in either PC3 or DU145 cell lines may represent the AR-independent mechanisms. In this context, the present study identified genes with mutations, expression changes and fusion transcripts in androgen-independent prostate cancer cells as compared to androgen-dependent cancer cells. 
Citation: Ma Y, Miao Y, Peng Z, Sandgren J, Díaz De Ståhl T, et al. (2017) Identification of Mutations, Expression Alterations and Fusion Transcripts by Next Generation RNAseq in Castration-Resistant Prostate Cancer Cell lines with Possible Clinical Relevance. Next Generat Sequenc \& Applic 4: 149. doi:10.4172/2469-9853.1000149

Page 6 of 8

Mutations are relatively common in cancer cell lines. They can be cancer specific mutations or random mutations acquired during the cell culture. To discriminate these random mutations, we used more than one cell lines and each cell line with triplicates. Furthermore, molecular changes in cell lines, despite not random, do not always represent molecular changes in tumor samples from patients.
A

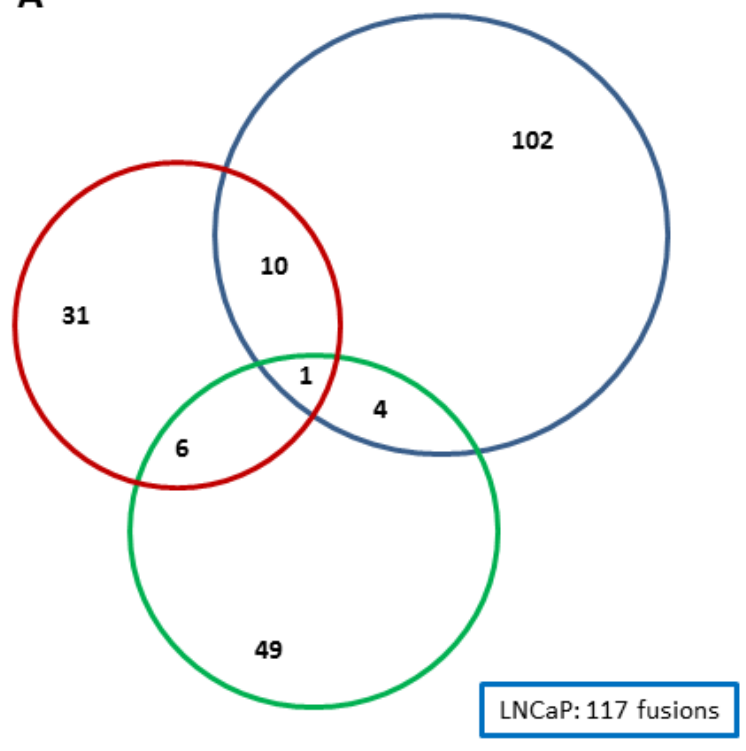

PC3: 60 fusions

DU145: 48 fusions
B

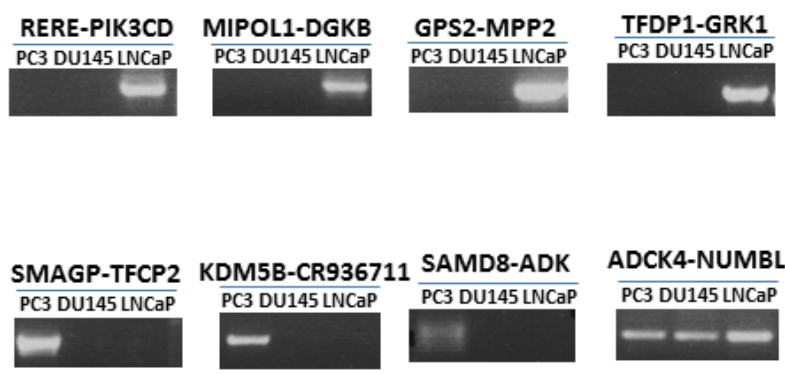

C
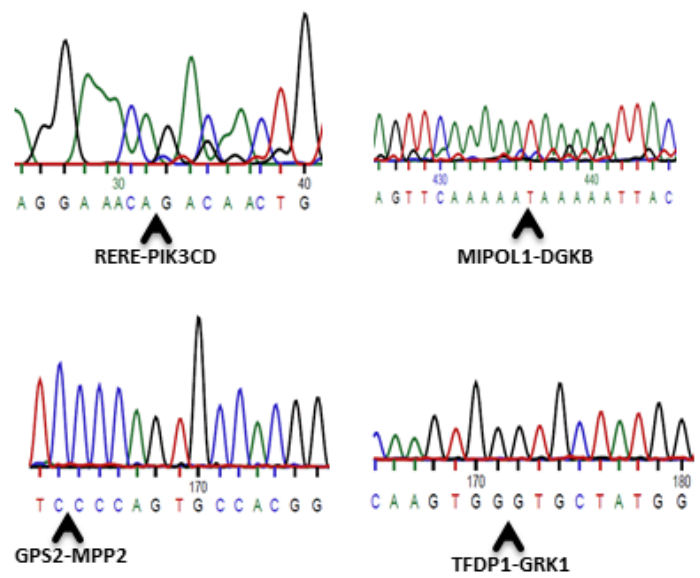

Figure 2: Fusion transcripts confirmed by PCR and Sanger sequencing.

To overcome this limitation, we focused on the importance of those molecular changes that have also been identified in tumor samples from patients in previously published results including the COSMIC database. Our study found 2579 mutated genes which were probably acquired when cells became resistant to hormone treatment. Among them, 1574 (61\%) could be found in mutations of Cosmic tumor samples, for instance, SPEG (1.7\%) and NCOR2 (1.6\%) in tumor samples (COSMIC).

Most interestingly, the most common pathway enriched with mutated genes in androgen-independent cell lines is the Immune response $\mathrm{B}$ cell antigen receptor (BCR) pathway, in line with a recent proposed concept epithelial immune cell-like transition (EIT) [37,38]. These findings may indicate that cancer cells can employ cytokine and immune pathways to suppress host's immune activity and escape from control and surveillance by immune system. Immunotherapy combined with hormone therapy could probably become effective treatments for metastatic prostate cancer.
The MetaCore analysis identified NR3C1, PRKACB, PRKD1 and PKD1 as the up-regulated genes with potential functions in hormone resistant cell lines. NR3C1 was significantly up-regulated in PC3 (expression level: 9.5) and DU145 (expression level: 63.8) compared with LNCaP (expression level: 0.2). NR3C1 encodes glucocorticoid receptor (GR), which shares several transcriptional targets with AR.

Previous researches showed that increased GR expression contributed to acquire resistance to ADT in prostate cancer in vitro and in vivo [39-41]. A phase II trial of enzalutamide (MDV3100) plus the glucocorticoid receptor antagonist mifepristone for patients with metastatic castration resistant prostate cancer (CRPC) has been performed (https://clinicaltrials.gov/ct2/show/study/NCT02012296? view=record).

PRKACB (protein kinase cAMP-dependent catalytic beta) is a member of serine/threonine protein kinase family and a key effector involved in proliferation, apoptosis metabolism and differentiation. In our study, it was down-regulated in PC3 (expression level: 8.9) and DU145 (expression level: 14.7), compared with LNCaP (expression 
Citation: Ma Y, Miao Y, Peng Z, Sandgren J, Díaz De Ståhl T, et al. (2017) Identification of Mutations, Expression Alterations and Fusion Transcripts by Next Generation RNAseq in Castration-Resistant Prostate Cancer Cell lines with Possible Clinical Relevance. Next Generat Sequenc \& Applic 4: 149. doi:10.4172/2469-9853.1000149

Page 7 of 8

level: 253.7). PRKD1 (protein kinase D1) is also known as protein kinase $\mathrm{C}$ mu (atypical PKC), which is a serine/threonine kinase and can be activated by PKC, involving various functions including adhesion, cell motility, and cell proliferation. PKD1 can interact with androgen receptor $(\mathrm{AR})$ and modulated $\mathrm{AR}$ function in prostate cancer [42-44]. In our project, PRKD1 was down-regulated in PC3 (expression level: 4.5) and DU145 (expression level: 5.4), compared with LNCaP (expression level: 100), showing that mRNA level was decreased in androgen-independent phenotype, which is similar to PRKACB above. PKD1 or PRKACB agonists or exogenous PKD1 may probably help to stop or slow down the progression of androgenindependent phenotype.

We also found several fusions which probably associated with resistance to hormone treatment. SMAGP-TFCP2, KDM5B-CR936711 and SAMD8-ADK was detected only in PC3 which were one of the androgen-independent cell lines in this study, while some fusions were androgen-dependent cell line (LNCaP) specific, including MIPOL1DGKB, GPS2-MPP2, TFDP1-GRK1, and RERE-PIK3CD. SMAGP (Small Cell Adhesion Glycoprotein) could bind as an enhancer with TFCP2 (Transcription Factor CP2), which activate transcription of genes, such as alpha-globin gene.

MIPOL1-DGKB had been found in LNCaP cell lines in previous study published in 2009 using RT-PCR and FISH [31], and the fusion point is the same with the fusion found in our project and cannot been read-through. GPS2-MPP2 found in our project had the same fusion point with previous study in LNCaP cell line, and was in-frame which could result in the expression a chimeric protein localized differently from wild-type GPS2 and MPP2 in cells and can promoted proliferation and protected against apoptosis [45]. TFDP1-GRK1 was also mentioned in previous bioinformatics studies without confirmation and function validation [46,47]. RERE-PIK3CD was found out of frame in our project. Among all fusion gene partners, GRK1 and PIK3CD expression were top 2 significantly down-regulated genes and TFCP2 was the most dramatically up-regulated gene [47-52].

\section{Conclusion}

Our study discovered mutations, fusion transcripts and genes with altered expression levels in castration-resistant prostate cancer cell lines, adding insights into androgen resistance in prostate cancer at transcriptomic level.

\section{Acknowledgements}

We thank SciLifeLab, Stockholm for their RNAseq technical support. The study was supported by research grants from the Swedish Cancer Society (Cancerfonden), the Cancer Research Foundations of Radiumhemmet and the Stockholm's County Council.

\section{Author Contributions}

Yuanjun Ma, Chunde Li and Sten Nilsson designed the study plan. Sten Nilsson, Lena Lennartsson, Zhuochun Peng and Chunde Li provided materials. Yuanjun $\mathrm{Ma}$, and Yali Miao performed all experiments. Yuanjun Ma, Johanna Sandgren, Teresita Díaz De Ståhl, and Chunde Li analyzed data together. Yuanjun $\mathrm{Ma}$ and Chunde $\mathrm{Li}$ wrote the manuscript. All authors revised the manuscript.

\section{References}

1. Ferlay J, Steliarova-Foucher E, Lortet-Tieulent J, Rosso S, Coebergh JWW, et al. (2013) Cancer incidence and mortality patterns in Europe: Estimates for 40 countries in 2012. Eur J Cancer 49: 1374-1403.

2. Gravis G, Fizazi K, Joly F, Oudard S, Priou F, et al. (2013) Androgendeprivation therapy alone or with docetaxel in non-castrate metastatic prostate cancer (GETUG-AFU 15): A randomised, open-label, phase 3 trial. Lancet Oncol 14: 149-158.

3. Gravis G, Boher JM, Joly F, Soulie M, Albiges L, et al. (2016) Androgen deprivation therapy (ADT) plus docetaxel versus adt alone in metastatic non-castrate prostate cancer: Impact of metastatic burden and long-term survival analysis of the randomized phase 3 GETUG-AFU15 trial. Eur Urol 70: 256-262.

4. Katzenwadel A, Wolf P (2015) Androgen deprivation of prostate cancer: Leading to a therapeutic dead end. Cancer Lett 367: 12-17.

5. Chandrasekar T, Yang JC, Gao AC, Evans CP (2015) Mechanisms of resistance in castration-resistant prostate cancer (CRPC). Transl Androl Urol 4: 365-380.

6. Neto AS, Tobias-Machado M, Wroclawski ML, Fonseca FLA, Pompeo ACL, et al. (2010) Molecular oncogenesis of prostate adenocarcinoma: Role of the human epidermal growth factor receptor 2 (HER-2/neu). Tumori 96: 645-649.

7. Traish AM, Morgentaler A (2009) Epidermal growth factor receptor expression escapes androgen regulation in prostate cancer: A potential molecular switch for tumour growth. Brit J Cancer 101: 1949-1956.

8. Culig Z, Hobisch A, Cronauer MV, Radmayr C, Trapman J, et al. (1994) Androgen receptor activation in prostatic tumor-cell lines by insulin-like growth-factor-i, keratinocyte growth-factor, and epidermal growth-factor. Cancer Res 54: 5474-5478.

9. Kojima S, Inahara M, Suzuki H, Ichikawa T, Furuya Y (2009) Implications of insulin-like growth factor-I for prostate cancer therapies. Int J Urol 16: 161-167.

10. Culig Z, Hobisch A, Bartsch G, Klocker H (2000) Androgen receptor- an update of mechanisms of action in prostate cancer. Urol Res 28: 211-219.

11. Majumder PK, Sellers WR (2005) Akt-regulated pathways in prostate cancer. Oncogene 24: 7465-7474.

12. Anvari K, Toussi MS, Kalantari M, Naseri S, Shahri MK, et al. (2012) Expression of Bcl-2 and Bax in advanced or metastatic prostate carcinoma. Urol J 9: 381-388.

13. Srivastava SK, Bhardwaj A, Singh S, Arora S, McClellan S, et al. (2012) Myb overexpression overrides androgen depletion-induced cell cycle arrest and apoptosis in prostate cancer cells, and confers aggressive malignant traits: Potential role in castration resistance. Carcinogenesis 33: 1149-1157.

14. Yokoyama NN, Shao S, Hoang BH, Mercola D, Zi X (2014) Wnt signaling in castration-resistant prostate cancer: Implications for therapy. Am J Clin Exp Urol 2: 27-44.

15. Zdanov S, Mandapathil M, Abu-Eid R, Adamson-Fadeyi S, Wilson W, et al. (2016) Mutant KRAS conversion of conventional $\mathrm{T}$ cells into regulatory T cells. Cancer Immunol Res 4: 354-365.

16. Shao DD, Xue W, Krall EB, Bhutkar A, Piccioni F, et al. (2014) KRAS and YAP1 converge to regulate EMT and tumor survival. Cell 158: 171-184.

17. Fu GP, Chen YH, Schuman J, Wang DM, Wen RR (2012) Phospholipase $\mathrm{C}$ gamma 2 plays a role in TCR signal transduction and T cell selection. J Immunol 189: 2326-2332.

18. Wang L, Wang J (2012) MicroRNA-mediated breast cancer metastasis: From primary site to distant organs. Oncogene 31: 2499-2511.

19. Shang YL, Smith S, Hu XY (2016) Role of Notch signaling in regulating innate immunity and inflammation in health and disease. Protein Cell 7: 159-174.

20. Zavadil J, Cermak L, Soto-Nieves N, Bottinger EP (2004) Integration of TGF-beta/Smad and Jagged1/Notch signalling in epithelial-tomesenchymal transition. Embo J 23: 1155-1165. 
Citation: Ma Y, Miao Y, Peng Z, Sandgren J, Díaz De Ståhl T, et al. (2017) Identification of Mutations, Expression Alterations and Fusion Transcripts by Next Generation RNAseq in Castration-Resistant Prostate Cancer Cell lines with Possible Clinical Relevance. Next Generat Sequenc \& Applic 4: 149. doi:10.4172/2469-9853.1000149

Page 8 of 8

21. Liu J, Cao XT (2016) Cellular and molecular regulation of innate inflammatory responses. Cell Mol Immunol 13: 711-721.

22. Du L, Ning ZF, Zhang H, Liu FX (2017) Corepressor metastasisassociated protein 3 modulates epithelial-to-mesenchymal transition and metastasis. Chin J Cancer 36: 28.

23. Ghoreschi K, Laurence A, O'Shea JJ (2009) Janus kinases in immune cell signaling. Immunol Rev 228: 273-287.

24. Dong Z, Tai W, Lei W, Wang Y, Li Z, et al. (2016) IL-27 inhibits the TGFbeta1-induced epithelial-mesenchymal transition in alveolar epithelial cells. BMC Cell Biol 17: 7.

25. Lee KZ, Kniazeva M, Han M, Pujol N, Ewbank JJ (2010) The fatty acid synthase fasn-1 acts upstream of WNK and Ste20/GCK-VI kinases to modulate antimicrobial peptide expression in $C$. elegans epidermis. Virulence 1: 113-122.

26. Li J, Dong L, Wei D, Wang X, Zhang S, et al. (2014) Fatty acid synthase mediates the epithelial-mesenchymal transition of breast cancer cells. Int J Biol Sci 10: 171-180.

27. Newton K, Dixit VM (2012) Signaling in innate immunity and inflammation. Cold Spring Harb Perspect Biol 4: a006049.

28. Melzer C, Hass R, Von Der Ohe J, Lehnert H, Ungefroren H (2017) The role of TGF-beta and its crosstalk with RAC1/RAClb signaling in breast and pancreas carcinoma. Cell Commun Signal 15: 19.

29. Thomson S, Petti F, Sujka-Kwok I, Mercado P, Bean J, et al. (2011) A systems view of epithelial-mesenchymal transition signaling states. Clin Exp Metastasis 28: 137-155.

30. Wan X, Huang W, Yang S, Zhang Y, Pu H, et al. (2016) Identification of androgen-responsive lncRNAs as diagnostic and prognostic markers for prostate cancer. Oncotarget 7: 60503-60518.

31. Maher CA, Kumar-Sinha C, Cao XH, Kalyana-Sundaram S, Han B, et al. (2009) Transcriptome sequencing to detect gene fusions in cancer. Nature 458: 97-101.

32. Qin FJ, Song ZG, Babiceanu M, Song YS, Facemire L, et al. (2015) Discovery of CTCF-sensitive Cis-spliced fusion RNAs between adjacent genes in human prostate cells. Plos Genet 11: e1005001.

33. Wang Y, Wang Y, Liu Q, Xu G, Mao F, et al. (2014) Comparative RNA-seq analysis reveals potential mechanisms mediating the conversion to androgen independence in an LNCaP progression cell model. Cancer Lett 342: 130-138

34. Yorukoglu D, Hach F, Swanson L, Collins CC, Birol I, et al. (2012) Dissect: Detection and characterization of novel structural alterations in transcribed sequences. Bioinformatics 28: i179-187.

35. Bennett NC, Hooper JD, Johnson DW, Gobe GC (2014) Expression profiles and functional associations of endogenous androgen receptor and caveolin-1 in prostate cancer cell lines. Prostate 74: 478-487.

36. Sampson N, Neuwirt H, Puhr M, Klocker H, Eder IE (2013) In vitro model systems to study androgen receptor signaling in prostate cancer. Endocr-Relat Cancer 20: R49-R64.

37. Choi SYC, Gout PW, Collins CC, Wang YZ (2012) Epithelial immune cell-like transition (EIT): A proposed transdifferentiation process underlying immune-suppressive activity of epithelial cancers. Differentiation 83: 293-298.

38. Ricciardi M, Zanotto M, Malpeli G, Bassi G, Perbellini O, et al. (2015) Epithelial-to-mesenchymal transition (EMT) induced by inflammatory priming elicits mesenchymal stromal cell-like immune-modulatory properties in cancer cells. Br J Cancer 112: 1067-1075.

39. Isikbay M, Otto K, Kregel S, Kach J, Cai Y, et al. (2014) Glucocorticoid receptor activity contributes to resistance to androgen-targeted therapy in prostate cancer. Horm Cancer 5: 72-89.

40. Arora VK, Schenkein E, Murali R, Subudhi SK, Wongvipat J, et al. (2013) Glucocorticoid receptor confers resistance to antiandrogens by bypassing androgen receptor blockade. Cell 155: 1309-1322.

41. Kroon J, Puhr M, Buijs JT, Van Der Horst G, Hemmer DM, et al. (2016) Glucocorticoid receptor antagonism reverts docetaxel resistance in human prostate cancer. Endocr Relat Cancer 23: 35-45.

42. Mak P, Jaggi M, Syed V, Chauhan SC, Hassan S, et al. (2008) Protein kinase D1 (PKD1) influences androgen receptor (AR) function in prostate cancer cells. Biochem Biophys Res Commun 373: 618-623.

43. Hassan S, Biswas MH, Zhang C, Du C, Balaji KC (2009) Heat shock protein 27 mediates repression of androgen receptor function by protein kinase D1 in prostate cancer cells. Oncogene 28: 4386-4396.

44. Syed V, Mak P, Du C, Balaji KC (2008) Beta-catenin mediates alteration in cell proliferation, motility and invasion of prostate cancer cells by differential expression of e-cadherin and protein kinase D1. J Cell Biochem 104: 82-95.

45. Teles AI (2015) Characterization of novel genetic alterations in prostate cancer, Ph.D. thesis, Erasmus University Rotterdam, Netherlands.

46. McPherson A, Wu CX, Hajirasouliha I, Hormozdiari F, Hach F, et al. (2011) Comrad: Detection of expressed rearrangements by integrated analysis of RNA-Seq and low coverage genome sequence data. Bioinformatics 27: 1481-1488.

47. DePristo MA, Banks E, Poplin R, Garimella KV, Maguire JR, et al. (2011) A framework for variation discovery and genotyping using nextgeneration DNA sequencing data. Nat Genet 43: 491-498.

48. McKenna A, Hanna M, Banks E, Sivachenko A, Cibulskis K, et al. (2010) The genome analysis toolkit: A MapReduce framework for analyzing next-generation DNA sequencing data. Genome Res 20: 1297-1303.

49. Trapnell C, Roberts A, Goff L, Pertea G, Kim D, et al. (2012) Differential gene and transcript expression analysis of RNA-seq experiments with TopHat and Cufflinks. Nat Protoc 7: 562-578.

50. Iyer MK, Chinnaiyan AM, Maher CA (2011) ChimeraScan: A tool for identifying chimeric transcription in sequencing data. Bioinformatics 27: 2903-2904.

51. Mi H, Muruganujan A, Thomas PD (2013) Panther in 2013: modeling the evolution of gene function, and other gene attributes, in the context of phylogenetic trees. Nucleic Acids Res 41: D377-386.

52. Huber-Keener KJ, Liu X, Wang Z, Wang Y, Freeman W, et al. (2012) Differential gene expression in tamoxifen-resistant breast cancer cells revealed by a new analytical model of RNA-Seq data. PloS one 7: e41333. 